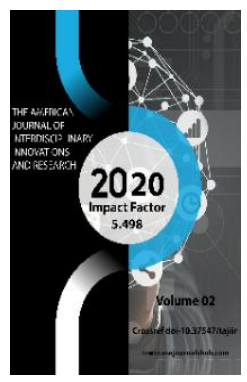

Journal Website: http://usajournalshub.c om/index,php/tajiir

Copyright: Original content from this work may be used under the terms of the creative commons attributes 4.0 licence.

\section{Small Torch Progress In Prospects Gold Mining In Improving Countries}

\author{
Khayitov Odiljon G'afurovich \\ Candidate Of Geological And Mineralogical Sciences, Associate Professor, Head Of The \\ Department "Mining", 100095, Republic Of Uzbekistan, Tashkent, University Street, 2, \\ Tashkent State Technical University, Uzbekistan
}

Umirzoqov Azamat Abdurashidovich

Phd Scholar Of The Department Of Mining, Tashkent City, 100095, Tashkent State Technical University Named After Islam Karimov, Uzbekistan

Bekmuratov Ajiniyaz Omirbek Ogli

Master, Tashkent State Technical University Named After Islam Karimov, Tashkent City, Uzbekistan., Uzbekistan

\title{
ABSTRACT
}

The World Gold Council and its member companies support the responsible mining and trading of gold from all legitimate sources, including artisanal and small-scale mining (ASM). The responsible development of gold resources both through large-scale mining (LSM) and ASM, especially when coupled with sound governance, has the potential to deliver broad social and economic benefits to individuals, communities and countries. There has been a significant growth in artisanal and smallscale mining in many developing countries over the last twenty years. ASM issues have become more salient in public policy debates as a result of the adoption of instruments designed to prevent the funding of illegal armed groups and from the implementation on reducing mercury in the environment. Artisanal and small-scale mining is more than simply an industry with the potential to contribute positively to foreign exchange earnings and employment; it is a way of life. Its participants, most of whom were lured into work by the prospect of gaining wealth quickly, include rural community dwellers, nomadic peoples, seasonal subsistence farmers, and retrenched largescale mine workers. However, despite providing higher wages than comparative rural sectors of industry, artisanal and small-scale mining is generally associated with a deteriorated quality-of life

\section{KEYWORDS}

Small-scale gold mining, explosive, gold mining, well spacing, rock, rock mass, blasting, rock strength, open pit mining, parallel-close charges. 


\section{INTRODUCTION}

Small scale gold mining operations have proven to be extremely harmful to the environment and result in adverse pollution of the atmosphere, soil degradation, landscape damage, ground and surface water contamination, flooding, deforestation and an aggregate of health related issues[1]. Bad mining practices are crucial to the environment, but most of the workers that are involved in the industry are of a poor social standing and lack basic knowledge about the potentially harmful outcomes. Environmental problems are overlooked by the small-scale minors and most governments where they operate mainly for a reason that the industry keeps the poor population employed and the small term economic gains prevail over long term environmental resolutions. The main issues covered in this work will be mercury pollution, specifically from the processes of mercury amalgamation with gold. Such pollution leads to diverse ecosystems destruction and poses a threat to fragile ecological communities. I will concentrate my research on the countries of South America such as French Guiana, Surinam, Guyana and Brazil. Pollution and degradation of water resources put a burden on many communities that rely primarily on various species of fish as their main food source[2]. But the governments of these countries are unable to implement effective regulations and policies that comply with the environmental standards of the developed word and those that would eliminate present day pollution issues. Environmental management initiatives and practices that are taking place in those countries and their effectiveness will also be discussed.As one mineral policy-maker put it during a personal interview, "almost every government in the Third World lacks the very information needed to implement effective artisanal and smallscale mining policies and regulations but most still go ahead and implement them anyway". It is safe to say that most governments have inadequate data concerning the locations of scores of relevant artisanal mining operations; what each is extracting and in what quantities; the nature of the technology being deployed at sites; and the groups of people involved [3]. Yet, governments around the world continue with reckless abandon to regularize resident artisanal and small-scale mining operations, despite clearly possessing insufficient knowledge of its mechanics and socio-cultural characteristics. As one African mineral policymaker put it during a personal interview, "almost every government in the Third World lacks the very information needed to implement effective artisanal and small-scale mining policies and regulations but most still go ahead and implement them anyway". It is safe to say that most governments have inadequate data concerning the locations of scores of relevant artisanal mining operations; what each is extracting and in what quantities; the nature of the technology being deployed at sites; and the groups of people involved[4].

The contributors to this volume are based in 22 countries-Australia, Austria, Bolivia, Brazil, Canada, Chile, China, Ghana, India, Indonesia, Kenya, Mozambique, the Philippines, South Africa, Suriname, Sweden, Switzerland, Tanzania, the UK, the USA, Zambia, Zimbabwe-and work in academia, government, the international agency and NGO sector, consultancies and industry. 
The first section explores the policy and legal environment for artisanal and small-scale mining. To effectively regulate, and support, such an industry, a plethora of issues must be addressed. The fact that artisanal and smallscale mining has long been treated as an informal sector of the economy requires that governments initially establish sound regulatory regimes for operations. This involves, inter alia, drafting pertinent legislation, creating procedurally simple licensing systems for small-scale miners, and analyzing the composition of the industry. Once the constituents and significance of a de facto and de jure legislative framework have been realized, governments should begin studying more in depth the nature of resident artisanal and small-scale mining operations, and use the recovered information to refine and strengthen existing regulations and policies, and establish robust industry support services[5]. The second section of the book"Artisanal and Small-Scale Mining, Labour and the Community"-examines the chief characteristics of artisanal and small scale mines, providing policy-makers with pertinent information concerning the state of the industry today. The remainder of the book is divided into three sections-“African Case Studies of Artisanal and Small-Scale Mining", "Asian Case Studies of Artisanal and SmallScale Mining", and "Latin American Case Studies of Artisanal and Small-Scale Mining". The collective aim of these sections is to provide the reader with up-to-date information on the state of artisanal and small-scale mining within the three continents where it occurs. The case studies presented provide an interesting and varied selection of perspectives concerning the socio-economic importance of the industry and the problems it has caused [6].

\section{MATERIAL AND METHODS}

An increasing number of rural inhabitants are turning to artisanal and small-scale mining in order to feed their families, further reinforcing assertions that the industry is "povertydriven". Some 10-15 years ago, many governments, amid claims of having finally recognized the potential economic value of the mineral outputs derived from artisanal and small scale mines, began implementing a series of policies that both legalized resident activities and regulated their production. Regional definitions of "artisanal" and/or "small-scale mining" were soon crafted and eventually embodied into national mineral legislation. Licensing and registration schemes were then created and enforced upon all existing and new mine operators; those choosing to function outside this newlyforged "legalized" industry segment were viewed as "clandestine" and "illegal". The impulsive decisions to license this rudimentary sector of industry have produced mixed results. On the one hand, by better regulating production, governments have inevitably improved control of mineral outputs that contribute positively to both national export earnings and foreign exchange[7]. For example, gold and gemstones reportedly valued at US\$1 billion a year are produced and collected by governments in sub-Saharan Africa. Moreover, in China, gold production from small-scale mining is currently worth about US\$200 million a year; in Bolivia and Brazil, US\$180 million; US\$140 million in Indonesia; and about US\$250 million in Peru. Artisanal and small-scale mining also provides employment to millions world wide; it has been conservatively estimated that between 11.5 and 13 million people are employed in the industry directly, and that as many as 100 million depend on its existence for their livelihoods. On the other hand, by rapidly 
implementing a series of policies and laws for artisanal and small-scale mines, governments have, in effect, introduced formalities to what has long been treated as an informal sector of industry; many miners have been unable, or are unwilling, to adapt to new regulatory regimes. As a result, authoritative bodies now face a plethora of unanticipated problems, such as rampant "illegal” (transient) mining, illicit mineral marketing activities, and land use disputes between small- and large-scale mining parties. These problems have been exacerbated by consistent failure on the part of governments to provide resident artisanal and small-scale miners with adequate support and extension services[8]. The industry's operators frequently lobby for increased financial assistance, improved equipment, and training, and regularly voice complaints over how they receive secondary treatment to large-scale mine operators. The primary objective of this introductory section is to examine many of the important regulatory issues and concerns in the artisanal and smallscale mining industry. It serves as an important backgrounder on the industry, profiling key policy and legislative-related issues. The first chapter, by Edmond Bugnosen, provides pointers to governments keen on implementing sector-specific legislation for small-scale mining. Apart from reviewing existing small-scale mining legislation in selected developing countries, the author uses the results and lessons learned to develop an appropriate small-scale mining legislative framework (Fig. 1-).

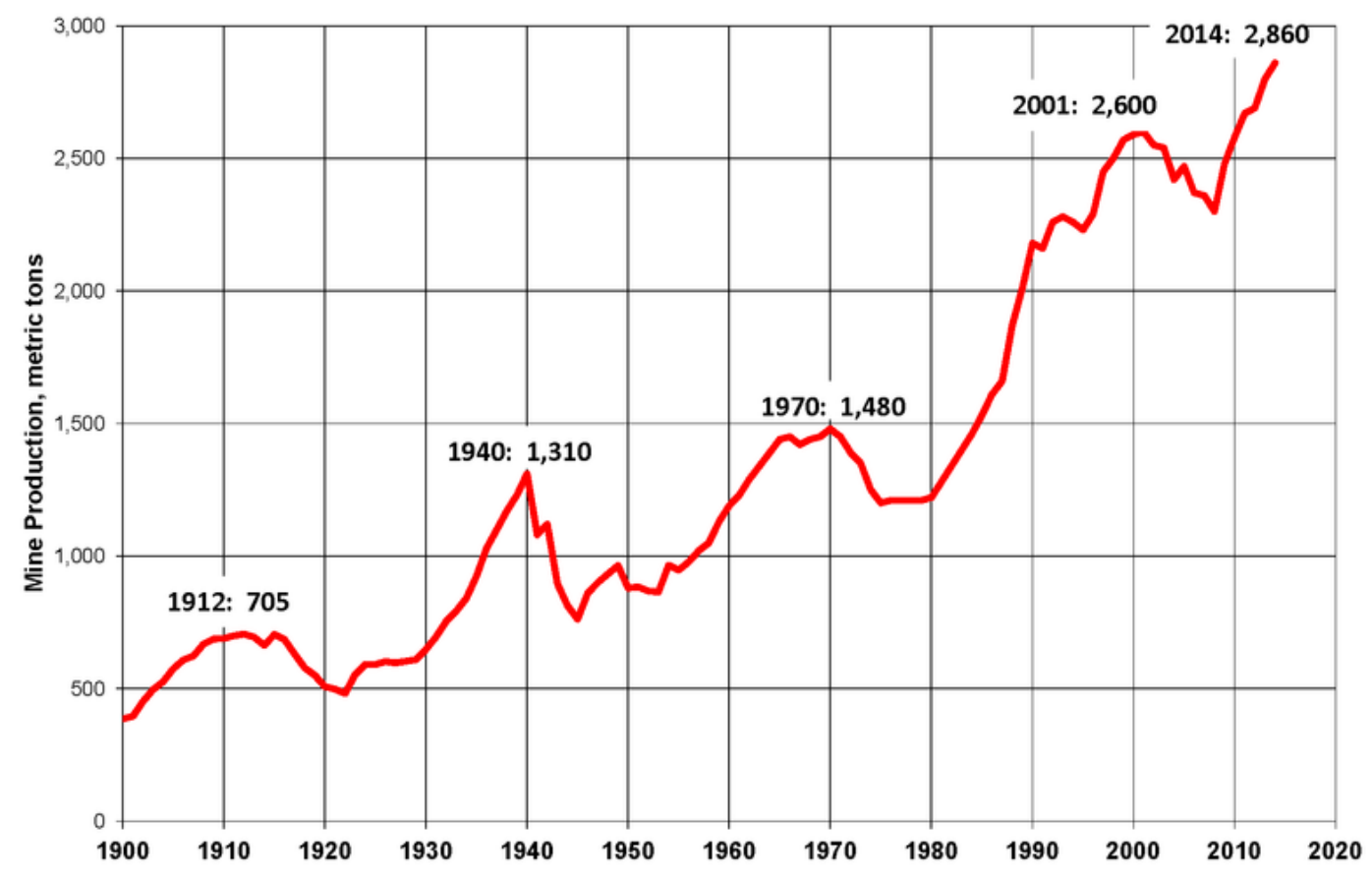

Fig. 1-Annual world mined gold production, 1900-2018 
In Chapter 3, John Andrew and Gavin Hilson describe the pervasiveness of the land use conflicts that often occur between small- and large-scale mining parties. The authors explain how, as a direct consequence of governments prioritizing the infusion of foreign large-scale mining activity, thousands of indigenous artisanal miners have been displaced[9]. The authors outline potential mediation procedures for resolving the inevitable ensuing land use disputes. Chapter 4, by Stephens Kambani, describes the characteristics of the "illegal mining segment", a label that has been a part of the mainstream mining lingo since the first efforts were made to regularize artisanal and smallscale mining activities. The author begins by examining the major issues concerning illegal mining and marketing in the small-scale mining sector in developing countries. Outside of a small group of initiatives undertaken by the World Bank, the International Labour Organization, and various branches of the United Nations, little research has been carried out to gain an improved understanding of the key anthropological characteristics of the industry, and its socio-economic impacts. Yet, governments around the world continue with reckless abandon to regularize resident artisanal and small-scale mining operations, despite clearly possessing insufficient knowledge of its mechanics and socio-cultural characteristics.

\section{RESULTS}

They further argue that the general theory of FDI is, in part, responsible for the misguided inadequacies of mining policies, particularly those pertaining to the small-scale mining industry. The chapter confirms that the theoretical underpinning of operating decisions in mining policy formulation is in dire need of modification. The concluding chapter of the section, by Michael Renner, profiles many of the wars that have occurred over mineral deposits-particularly, diamonds. Case studies are presented from Africa and Asia that illustrate how, in many states with weak authority, rebel parties have seized control of mineral resources; this has precipitated war between anarchic groups, some of which have been sponsored by outside governments. The overarching aim of this introductory section is twofold. First, it describes many of the challenges associated with regularizing artisanal and small-scale mining. Secondly, it illustrates the problems that can come about if cavalier approaches are taken to regulate the industry[10].

Philippines tried to address this problem through special legislation to regulate gold panning and sluicing inside existing mining claims. In a way, the legislation allows double licensing over the same area, but proved ineffective due to non-issuance of consent by concession holders. There are, however, other mechanisms available to legalise small-scale mining within existing mining concessions[11]. These include tributing arrangements, operating agreements and contract mining. Most are initiated by the parties themselves, or are performed with the assistance of authorities, as in the case of Papua New Guinea, where the government, through the Department of Mines, has actually prepared standard tributing contracts. This "privatised licensing scheme" of small-scale mining has been reportedly adopted in Mongolian legislation as well; in Mongolia, licence holders are encouraged to contract Small-scale mining legislation 13 out (to small-scale miners) portions of the deposit that may not be viable to exploit using conventional (large-scale) 
industrial techniques. On the other hand, it is mandatory in many countries for large-scale concession holders to gradually reduce the size of their concessions as exploration progresses. By this process, small deposits that are of no interest to the licence holders are effectively relinquished. These areas should then revert back to the government, and opened for location by small-scale miners[12]. Of the material that does exist, most generally originates from narrative accounts, and, collectively, covers only a small group of countries. In Ghana, the promulgation of the Minerals and Mining Law in 1986, and the establishment of the Minerals Commission to regulate and manage the utilization of the country's mineral resources and co-ordinate policies in relation to them, has been instrumental in the rapid growth of the gold-mining sector. The later adoption and implementation of small-scale mining legislation has reportedly resulted in the provision of systematic support to the smallscale mining sector. Between 1991 and 1994 exports of gold and diamond increased by $61 \%$ and $142 \%$ respectively, largely because of reforms made to small-scale mining policy. It has also been observed that the legislation resulted in better and realistic pricing of minerals, the collection of a land reclamation fund through buyers, and the creation of over ten thousand jobs after the first year of implementation. The regulation has been described as lacking a long-term vision for the activities of alluvial goldpanners[13]. In Brazil, although the need for effective licensing and regulatory procedures is recognized, "the great majority of mining operations are unauthorized and unregulated and the environmental and social consequences are serious".

DISCUSSIONS
The socio-economic impacts of Artisanal and small-scale mining 14 In the Philippines, the licensing of small-scale sand and gravel extraction activities has provided local governments with a new source of revenue, particularly in the form of royalty fees. Some local governments have even instituted checkpoints to ensure that all extraction is performed legally and that royalty fees are paid. This has created several small business opportunities such as trucking, manufacturing of building materials (hollow blocks), and the trading of sand and gravel concessions[14]. Gold panning is mostly a manual technique of separating gold from other materials. Wide, shallow pans are filled with sand and gravel that may contain gold. The pan is submerged in water and shaken, sorting the gold from the gravel and other material. As gold is much denser than rock, it quickly settles to the bottom of the pan. The panning material is usually removed from stream beds, often at the inside turn in the stream, or from the bedrock shelf of the stream, where the density of gold allows it to concentrate, a type called placer deposits. Gold panning is the easiest and quickest technique for searching for gold, but is not commercially viable for extracting gold from large deposits, except where labor costs are very low or gold traces are substantial. Panning is often marketed as a tourist attraction on former gold fields [15].

\section{CONCLUSIONS}

Leading LSM operators also implement international standards, in areas like disclosure of payments to government, cyanide management and conflict-sensitive business practices. Moreover, LSM typically requires significant upfront investment conducted over many years, in order to bring to account what are often geologically or metallurgically complex gold resources. LSM 
firms will also often be required to deploy financial and technical expertise and resources without which it would not be possible to develop a deposit for the benefit of the host country and its people. For hours, children dig, crush, mill, and haul ore in the hot sun. Children stand in water, digging sand and silt from riverbeds. They carry heavy bags of mud with their heads to designated sieving and washing sites. Children suffer the effects of noise, vibration, overexertion, poor ventilation, and exhaustion. Children's lives are put at risk by rock fall, explosions, the collapsing of tunnels and mine shafts, falling into open shafts and pits, and breathing air polluted by dust and toxic gas. Having immune systems that are not fully developed makes children especially vulnerable to dust and chemical exposure. Injuries include serious respiratory conditions, constant headaches, hearing and sight problems, joint disorders and various dermatological, muscular and orthopaedic ailments and wounds.

\section{ACKNOWLEDGEMENTS}

Although there are large industrial mines worldwide, artisanal mines employ about ten times as many people, typically workers who are not eligible for employment in industrial mining due to a lack of formal education and experience. Furthermore, small miners' earnings tend to be spent locally or sent as remittances to other poor communities, supporting sustainable economic growth in local communities. Based on the developed methodology, a computer-based calculation program has been compiled to select the optimal options for developing small-scale.

\section{REFERENCES}

1. "Global Trends in Artisanal and Small-Scale Mining (ASM): A review of key numbers and issues". IISD. 2018-01-20. Retrieved 2018-10-26.

2. "Learn more about child labour in mining (IPEC)". Retrieved 16 December 2016

3. Jump up to: Ingram, V., et al. (2011). "Where artisanal mines and forest meet: Socio-economic and environmental impacts in the Congo Basin." Natural Resources Forum: A United Nations Sustainable Development Journal. 35(4), 304-320.

4. Mislibaev IT, Soliev B.Z. A complex study of the physico-chemical properties of an array of strong sandy rocks // Gorny Vestnik of Uzbekistan. - Navoi, 2017. - № 2. - P. 23-25.

5. Hardy M, Agapito JFT (1975) Pillar design in underground oil shale mines. In Fairhurst, Crouch SL (eds) Design methods in rock engineering. Proceedings 16th US-rock mechanics symposium. US Rock Mechanics Society. New York, ASCE, pp 257-265

6. Hanukaev A.N. The energy of stress waves in the explosion of rocks by explosion. - M., 2012. - $200 \mathrm{p}$.

7. Mislibaev I.T., Tukhtashev A.B., Giyazov O.M., Soliev B.Z. The change in the strength of the rock massif, depending on the design of the wells of borehole charges of explosives, Izvestiya Vysshikh Uchebnykh Zavedenii. Mountain magazine. - Ekaterinburg: ed. UGSU, 2017. - № 3. - P. 45-50.

8. Nasirov UF, Tukhtashev AB, Ochilov Sh.A., Ravshanova M.Kh. Determination of effective parameters of paralleled borehole charges in the production of mass explosions on high ledges // Izvestiya Vuzov. Mountain magazine. Ekaterinburg: ed. UGSU, 2017. - № 3. - P. 64-71.

9. Nasirov U.F., OchilovSh.A., Umirzoqov A.A. Analysis of Development of Low-Power 
and Man-Made Gold Deposits// International Journal of Academic and Applied Research (IJAAR)ISSN: 2643-9603 Vol. 4, Issue 4, April - 2020, Pages: 71-74. http://ijeais.org/wpcontent/uploads/2020/4/IJAAR200414.pdf

10. Umirzoqov A.A., Jurayev S.J., KaramanovA.N. Economic and mathematical modeling of rational development of small-scale and man-made gold deposits// International Journal of Academic and Applied Research (IJAAR), Vol. 4, Issue 4, April - 2020, Pages: 75-77. http://ijeais.org/wpcontent/uploads/2020/4/IJAAR200415.pdf

11. Hayitov O.G., Umirzoqov A.A., Iskandarov J.R., Suvanov F.R. Prospects for the industrial use of coal in the world and its process of reproducing// Novateur Publication's JOURNALNX- A Multidisciplinary Peer Reviewed Journal, Volume 6, Issue 5, may-2020, Pages:240247. https://journalnx.com/journalarticle/20151009

12. OchilovSh.A., Umirzoqov A.A., KaramanovA.N., Ergashev O.S. Calculation of the Optimal Distance Between ParallelConverged Charges When Exploding High Ledges// International Journal of Academic Management Science Research (IJAMSR), Vol. 4 - Issue 6 (June - 2020), Pages:57-61. http://www.ijeais.org/ijamsr/index.php/ijam sr-4-6-2020/

13. Kazakov A.N., Umirzoqov A.A., Radjabov Sh.K., Miltiqov Z.D. Assessment of the Stress-Strain State of a Mountain Range// International Journal of Academic and Applied Research (IJAAR), Vol. 4 - Issue 6 (June - 2020), Pages:17-21. http://www.ijeais.org/ijamsr/index.php/ijam sr-4-6-2020/

14. Nasirov U.F., Ochilov Sh.A., Umirzoqov A.A. Theoretical Calculation of the Optimal
Distance between Parallel-close Charges in the Explosion of High Ledges//(SCOPUS) Journal of Advanced Research in Dynamical and Control Systems - JARDCS, Vol. 12,07special issue, 2020, Pages: 2251-2257. https://www.jardcs.org/abstract.php?id=57 78

15. Umirzoqov A.A., Karamanov A..N., Radjabov Sh. K. Study of the feasibility of using intermediate buffer temporary warehouses inside the working area of the Muruntau quarry// International Journal of Engineering and Information Systems (IJEAIS), Vol. 4, Issue 8, August - 2020, Pages140-142.

http://www.ijeais.org/ijeais/index.php/ijeais $-4-8-2020 /$ 